\title{
The Stimulus Response-Cooperative Script Model in Storytelling Learning with Character Content
}

\author{
Atikah Anindyarini ${ }^{1}$, Fathur Rokhman', Mimi Mulyani², and Andayani ${ }^{1}$ \\ \{atikahanindyarini@gmail.com ${ }^{1}$ \} \\ ${ }^{1}$ Universitas Sebelas Maret, Surakarta, Indonesia \\ ${ }^{2}$ Universitas Negeri Semarang, Semarang, Indonesia
}

\begin{abstract}
The problems the students encounter in storytelling learning are less self-confidence to appear before the class and public speaking anxiety. Therefore, a stimulus response-based cooperative script model is developed in storytelling speaking learning with character content to reduce the students' public speaking anxiety. This study was a research and development (R \& D) with operational research type, conducted in 6 schools in Surakarta. Interview, questionnaire distribution, and Focus Group Discussion were used for collecting data. Data analysis technique used was an interactive model of analysis encompassing data reduction, data display, and verification. This article aimed to elaborate a stimulus response-based cooperative script model in storytelling learning with character content in detail. In this model, the students told story in pair, observed their partner's performance, and then responded to their partner's storytelling by assessing and commenting on storytelling performance and attitude. They responded positively to the model developed. They did storytelling more confidently, because it gave an opportunity of practicing and of getting response from the partner. In conclusion, the stimulus response-based cooperative script model applied in storytelling with character content effectively improved the students' confidence and storytelling skill.
\end{abstract}

Keywords: storytelling skill, speaking anxiety, cooperative script, stimulusresponse, character

\section{INTRODUCTION}

Life is inseparable from story. There will always be story from birth, death to happy or saddening event. Everyone loves story, and so do the children. They always wait for story or fairy tale told by teacher.

Storytelling becomes effective because story is generally more impressive than advice. Story is recorded more strongly than advice in child's brain memory. Through story, children is taught to take lesson without feeling being instructed [1].

Storytelling has been used as a teaching tool since a long time ago, either to inculcate the values contained in much folklore or to merely deliver information. Then, teacher makes debriefing with the students concerning the content of story. In addition, teacher can instruct the students to retell the story they have read. However, the data in the field shows that oral 
storytelling learning occurring in the class has not run optimally yet so far. Some problems are still found when the students tell story before the class. Teachers (SHR, DW, SKN, DT, and IND) said that the constraint the students face during oral storytelling before the class relates to less self-confidence [2]. It is in line with Chaniago and Bobanovic and Bobanovic. They feel nervous, forget suddenly, and develop pounding so that they can say nothing [3]. Meanwhile, North \& Rives in Babanovic and Bobanovic explain that the factor causing most students not willing to speak in language learning is their anxiety to speak before their friends [4].

The skill of expressing idea in written and spoken ways is very important to master to the students in this century. It has also been stated in the Curriculum 2013. The competencies to be mastered by students, according to the Curriculum 2013, are communicating, collaborating, critical thinking, problem solving, and creative competencies [5].

Storytelling competency as the part of speaking skill should be practiced and developed continuously, so that the students will be accustomed to expressing their thought, feeling, and idea well and confidently. Regarding speaking ability, Tarigan stated that the main objective of speaking is to communicate [6]. To deliver effective information, the speaker should actually understand its speaking content, in addition to it should be able to evaluate its communication effect on its listeners.

To solve the problem related to students' poor self-confidence during storytelling before the class, a model is required to motivate the students to improve their self-confidence. The model offered is stimulus response-based script cooperative model. Considering the elaboration above, in this article the author is interested in elaborating "The Stimulus Response-Cooperative Script Model in Storytelling Learning with Character Content".

\section{METHOD}

This study was a research and development $(\mathrm{R} \& \mathrm{D})$ in the form of operational research [7]. Overall, the Borg and Gall's researched and development procedure, as developed by Sukmadinata et al, consists of three stages: 1) preliminary study, 2) model development, and 3) model trial [8]. The data of research was obtained from the result of interview and the distribution of questionnaire to teachers and students in 6 schools (SMP 2, SMP 5, SMP 14, SMP 19, SMP Al Islam and SMP Al Abidin). In addition, Focus Group Discussion was also held to get input from teachers, coworkers, and practitioners concerning the learning model developed. This research was conducted for 1 year, from June 2017 - June 2018. To validate the data, source and method triangulations were used. Technique of analyzing data used in this research was an interactive model of analysis [9]. The mechanism of interactive analysis basically involves three components of analysis: data reduction, data display, and verification.

\section{RESULT AND DISCUSSION}

In relation to the method of retelling a story orally, the problem most students face is that they have less self-confidence to tell story before the class. The students develop speaking anxiety. This speaking anxiety affects the students' successful language learning. It is in line with Bodie (in Morgan and Schmidt) stating that public speaking anxiety affects the students who learn language [10]. Furthermore, Woodrow (in Morgan and Schmidt) confirms that anxiety an individual develops in communicating in certain language can attenuate and can affect the students' adaptation to environment and their achievement of education objective [10].

Kelly (in Morgan and Schmidt 2012) states that one of techniques to reduce speaking anxiety is skill practicing, by means of learning and practicing [10]. This technique is targeted to improve individual's language behavior. It is in line with this model giving the participants the 
opportunity of practicing. To solve the problem, storytelling in group becomes an alternative to deal with students' storytelling anxiety before the class.

The model developed to improve the students' storytelling skill is stimulus response-based cooperative script model. In this model, the students tell the story in pair. They are given an opportunity of practicing along with their friend in pair. Through practicing in pair, they observe their partner's performance based on storytelling assessment indicator specified by teacher. Thereafter, the students serving as observer respond to their partner's storytelling. Thus, it is conducted in pair.

In storytelling learning, all students are given an opportunity of practicing storytelling. Before they do storytelling, teachers show a video depicting 2 persons doing storytelling, using stimulus response-based cooperative script model (SRBCSM). The students were told to observe the video and then to practice it along with their partner.

The procedure of learning model using stimulus response based-cooperative script model in storytelling learning with character content (SRBCSM) is explained below [2]:

- Teacher explains the procedure of stimulus response based-cooperative script model (through LCD screen) as follows:

- Students sit down in pair with the partner specified by teacher.

- $\quad$ Student receive fantasy story text from teacher

- Students read and understand the text they read

- $\quad$ Students discuss the text they have read in pair

- The students receive the message of story

- The students organize the frame of story in pair or individually to facilitate storytelling.

- Students practice storytelling individually with the story frame help

- Students practice storytelling individually without the story frame help

- Having practiced storytelling individually, a students does storytelling with the partner listening to him/her

- $\quad$ Students do storytelling in turn

- If A does storytelling, B listening to him/her while noting his/her partner's strength and weakness in storytelling (the listener observes indicator for the storytelling assessment)

- If A has done storytelling completely, it is B's turn to do so.

- After both of them have done storytelling completely, they give their note on their partner's strength and weakness (Based on the indicator of assessment). The students of course should be taught by means of criticizing their friend politely.

- The indicator of storytelling assessment contains 7 aspects: content, diction, selfconfidence, fluency, intonation, spelling, and expression. If their partners do storytelling less fluently, the students can help to remind and to motivate each other.

- In the process of practicing storytelling in pair, characters of appreciating achievement, friendliness or communicativeness, social care, and language politeness are developed.

- They can give input to their partners' attitude including their strength and weakness.

- To facilitate the students to apply the storytelling practice, teachers show storytelling practice through storytelling video performed by the model.

- The students listen to the explanation through video show and pay attention to the model practicing storytelling in pair.

- Teachers give the students the opportunity of responding to or asking about what they have watched in the video show.

- The students practice storytelling in pair corresponding to the model developed. 
From the model elaborated above, it can be seen clearly that the model integrates the storytelling learning with character content into stimulus response-based cooperative (particularly cooperative script) learning. In this model, the students tell the story in pair. They are given an opportunity of practicing in pair. Originally, they practice individually without the story frame. Then, they practice in pair. During practicing storytelling in pair, they observe their partner's storytelling performance. Thereafter they respond to it by assessing and commenting on their partner's performance. The assessment is made not only on the storytelling performance including content, diction, self-confidence, fluency, intonation, spelling, and expression but also on the attitude including appreciating achievement, friendliness or communicativeness, social care, and language politeness. The assessing students have been equipped with assessment note containing some point marked.

The storytelling learning procedure using stimulus response-based cooperative script model has been arranged clearly and systematically. The correctly implementation of cooperative model procedure will enable the educators to manage the class more effectively. It is confirmed by Lie stating that to achieve the maximum result, five elements should be applied in cooperative learning [11]. They are: (1) positive interdependence, (2) face-to-face interaction, (3) individual accountability, (4) communication between members, and (5) group process evaluation. The storytelling learning procedure developed (SRBCSM) has fulfilled what has been suggested by Lie. In storytelling learning process, all group members are expected to exert positive effect on each other and be responsible for the assignment to be done. Hsiung says that much existing evidence shows that students learning cooperatively benefit significantly from their performance [12]. However, soon or later most cooperative learning teams should deal with one or more members, the action of which interferes with the team. If this problem is not solved immediately, the cooperative learning team becomes dysfunctional gradually and the advantage of cooperative learning decreases. To anticipate the weakness existing in the cooperative learning, teacher should give not only group assignment but also individual one to achieve the group objective. Just like the application of SRBCSM, although the model used is cooperative in nature, every individual remains to get individual task.

Cooperative learning has also been conducted by Nystrand. He explained that cooperative learning in small group is more effective than competitive and individualistic learning [13]. Furthermore, it can be concluded that the use of small group help students think and reason of the letters presented. In addition, language teacher should be able to motivate the language learner by saying that making error in language learning is something reasonable.

Stimulus response-based cooperative script model is the appropriate model to apply in storytelling learning. With two members in a group, the students will of course interact, communicate, and evaluate their partner's appearance more easily and effectively. A number of field studies show that when given correct instruction, students can learn in pair more effectively in small group. Dansereau and coworkers explain that the learning with cooperative script is the one consisting of two students conducting social interaction when they study text material. Dansereau et. al. (in Soelistiyanto) states that cooperative script is learning method when students work in pair and orally review the parts of material studied [14].

According to Slavin, cooperative learning refers to a variety of learning method. In this study, the students work in small groups helping each other in studying the learning material [15]. In cooperative class, the students are expected to help, discuss, and argument each other to sharpen the knowledge they master at that time and close the gap in their own understanding. In line with this, Lie (2003) states that teaching system giving the students the opportunity of cooperating with their friends in structured tasks is called cooperative teaching system [11]. 
In the presence of students' opportunity to interact, communicate, and evaluating the partner's performance in this model is called stimulus response-based learning. The learning with stimulus-response strategy is an effective strategy to apply to speaking skill. It is also confirmed by Iskandarwassid and Sunendar state that speaking learning strategy refers to stimulus-response principle [16].

In storytelling process, the students give feedback each other on their partner's appearance during storytelling, by means of considering the indicator of assessment including content, diction, self-confidence, fluency, intonation, spelling, and expression. Conflict or deviation leads an individual to rearrange and reconstruct his/her existing knowledge base. As such, they provide new understanding and better information retention. Interaction is the factor accelerating the positive growth. It because interaction can occur if only an individual sees faceto-face and communicate with others. Learning occurs through such interaction. Putting the students together can lead to an activity that can yield a knowledge construction in the learning. Cooperative learning can be used to improve the students' achievement and other positive consequences that can develop intergroup relation and acceptance to the classmates having poor academic performance, and improve self-esteem [15].

In line with this, Lie states that class circumstance should be planned and built in such a way that students are given the opportunity of interacting with each other [11]. In this interaction, the students will create community enabling them to love learning process and to love each other.

The importance of cooperation in learning is also confirmed by Thornley in Lickona. He states that when there was an oversight we have done for many years, that is our action leaving our children to stay silently on their seat rather than teaching them to cooperate [17].

In storytelling practice using SRBCS model, the students also give assessment on the students' attitude in storytelling. The students' attitudes observe are appreciating achievement, social care, friendliness/communicativeness, and language politeness. Not only is this SRBCS model applied aiming to improve the storytelling skill. But also, the students are expected to be more motivated to develop good characters through the storytelling learning process with character content.

Positive and negative feedback delivered by students to another in the learning process will grow their spirit and motivation. Social relation between students will improve. It will impact on the students' achievement. It is in line with Suhaida states that his research on cooperative learning is used to measure peer interrelationship [18]. Some students reported that their social relation with their group members improve in cooperative learning environment.

A successful cooperative learning is also shown by Nen-chen. Nen-chen has examined whether or not cooperative learning can improve the students' learning outcome in passive learning environment [19]. This study found that the students taught using cooperative learning approach significantly excel those taught using traditional lecturing format. This study also found that students in cooperative learning session answer the question significantly better than those learning in traditional lecturing session [20].

After the application of SRBCS model in storytelling learning, most students respond positively. It is in line with the hypothesis stating that students will prefer working cooperatively to working individually. Everyone existing in the class using cooperative learning can see that students indeed enjoy the cooperation with their peer. When students are asked whether or not they love working cooperatively and whether or not they want to do so again, they will say enthusiastically that they want to do so again [15]. 


\section{CONCLUSION}

In the learning process, teachers should make the students active. In storytelling learning, to improve the quality of process and product, a stimulus response-based cooperative script model (SRBCSM) is developed. In this model, the students are given an opportunity of doing storytelling in pair. During practicing in pair, they observe their partners' appearance based on the storytelling assessment indicator specified by teacher. Thereafter, the students serving as observer will respond to their partners' storytelling. It is conducted in turn. The presence of positive and negative feedback conveyed by students on others in the learning process will grow the students' learning spirit and motivation. It will impact on the students' achievement.

The stories told by students are those containing character education. During storytelling process, the students' attitudes in doing storytelling are also observed. The attitudes observed include: appreciating achievement, social care, friendliness, communicativeness, and language politeness. The students' respond to the model developed is highly positive. Students do storytelling more confidently because in the storytelling process they are given opportunity of practicing along with their partners and being responded to by their partners.

Thus, to improve the students' speaking skill, particularly storytelling skill, it is very appropriate to apply this stimulus-response model to the learning. Teacher should stimulate the students to do storytelling, give the students the opportunity of doing and practicing storytelling, and motivate the students to give feedback bravely on their partners during storytelling. In conclusion, the stimulus-response based cooperative script model applied in storytelling learning with character content effectively improved students' self-confidence and storytelling skill.

\section{REFERENCES}

[1] J. Hana and S. Psi, Terapi Kecerdasan Anak dengan Dongeng. Yogyakarta: Berlian Media, 2011.

[2] A. Anindyarini, F. Rokhman, M. Mulyani, and M. Andayani, "Storytelling Learning with Character Content Using Stimulus-Response Method," in International Conference on Science and Education and Technology 2018 (ISET 2018), 2018.

[3] S. Chaniago, J. Badusah, and M. Embi, "Teaching problems in language skills at Indonesian schools," Malay Lang. Educ. J., vol. 1, pp. 109-122, 2011.

[4] K.-B. Moira and M. Bobanović, "Foreign language skills in Business Communication," in 32nd International Conference on Organizational Science Development, 2013, pp. 415-422.

[5] H. Kurniawan, Literasi dalam Pembelajaran Sejarah. Yogyakarta: Gaya Media, 2018.

[6] H. G. Tarigan, "Berbicara Sebagai Suatu Keterampilan Berbahasa Indonesia," Bandung: Angkasa, 2008.

[7] M. D. Gall, W. R. Borg, and J. P. Gall, Educational research: An introduction. Longman Publishing, 1996.

[8] N. S. Sukmadinata, "Metode Penelitian Pendidikan, PT Remaja Rosdakarya." Bandung, 2012.

[9] M. B. Miles, A. M. Huberman, M. A. Huberman, and M. Huberman, Qualitative data analysis: An expanded sourcebook. sage, 1994.

[10] T. Docan-Morgan and T. Schmidt, "Reducing public speaking anxiety for native and non-native English speakers: The value of systematic desensitization, cognitive restructuring, and skills training," Cross-Cultural Commun., vol. 8, no. 5, p. 16, 2012. 
[11] A. Lie, "Cooperative Learning: Changing Paradigms of College Teaching," 2005. [Online]. Available: http://www.petra.ac.id/anitalie/LTM/Cooperative_Learning.htm.

[12] C. Hsiung, "The effectiveness of cooperative learning," J. Eng. Educ., vol. 101, no. 1, pp. 119-137, 2012.

[13] M. Nystrand, A. Gamoran, and M. J. Heck, "Using small groups for response to and thinking about literature," English J., vol. 82, no. 1, pp. 14-22, 1993.

[14] E. Soelistiyanto, "Penerapan Pembelajaran Model Cooperative Script Untuk Meningkatkan Hasil Belajar Pada Pokok Bahasan Evolusi Di Kelas Xii Ipa3 Sma Negeri 2 Jember," Pancar. Pendidik., vol. 3, no. 4, pp. 37-46, 2014.

[15] R. E. Slavin, Kooperatif: Teori, Riset, dan Praktik. Bandung: Nusa Media, 2005.

[16] Iskandarwassid and D. Sunendar, Strategi Pembelajaran Bahasa. Bandung: Remaja Rosdakarya, 2008.

[17] T. Lickona, E. Schaps, and C. Lewis, "Eleven Principles," 2002.

[18] S. A. Kadir, S. L. Wong, Z. A. L. Pihie, Yaacob;, and N. Fauziah, "The Effects of Kooperatif Strategy on Peer," Pakistan J. Psychol. Res., vol. 20, no. 3/4, pp. 121-131, 2005.

[19] N.-C. R. Hwang, G. Lui, and M. Y. J. W. Tong, "An empirical test of cooperative learning in a passive learning environment," Issues Account. Educ., vol. 20, no. 2, pp. 151-165, 2005.

[20] K. Saddhono and M. Rohmadi, "A Sociolinguistics Study on the Use of the Javanese Language in the Learning Process in Primary Schools in Surakarta, Central Java, Indonesia." Int. Edu. Stu., vol. 7 no.6 pp 25-30, 2014 